\title{
IDENTIFICATION OF MOBILE PHONE USAGE'S SHIFTING AMONG STUDENTS
}

\author{
Deni Sutisna, Arif Widodo, Ashar Pajarungi Anar, Dyah Indraswati*, Nursaptini \\ Elementary Teacher Education Study Program, Universitas Mataram, Indonesia \\ *E-mail : dyahindraswati@unram.ac.id \\ Website: http://jurnal.uin-antasari.ac.id/index.php/itijk \\ Received: 9 March 2020; Accepted: 29 September 2020; Published: 16 December 2020
}

\begin{abstract}
This study aims to identify the use of mobile phones in SMAN 1 Pangalengan. The survey was conducted on 100 students. Data collection using a questionnaire. Data analysis uses quantitative descriptive methods. The results showed students tend to utilize social media such as Facebook, Instagram, and WhatsApp. Other uses for browsing, gaming, and entrepreneurship. Survey results show that $92 \%$ of students use WhatsApp to communicate and $82 \%$ of students use mobile phones to access social media. This shows the pattern of mobile phone use has shifted among students although basically, it does not change the main function.
\end{abstract}

Key Words: friction; communication pattern; mobile phone; social media.

\section{INTRODUCTION}

The 21st century, known as the information technology century, or the era of the industrial revolution 4.0, is marked by the very fast development of information technology. (Widodo, Indraswati, \& Sobri, 2019). In the world of education, technology plays an important role, so that the development of the learning process becomes more modern. In this 21st-century education demands that all elements of education be able to master information and communication technology (Indraswati, Marhayani, Sutisna, Widodo, \& Mauilida, 2020) Mobile phones or better known as cellphones are wireless communication tools that can be carried anytime and anywhere. Mobile phone is the result of the development of conventional telephones with cables that are combined with radios to produce cordless telephones (Mulyanta, 2005). This innovation's result is become more effective and efficient tool of communication than landline phone. Along with technological developments, mobile phones have evolved into sophisticated communication tools. Not only for calling, but equipped with the latest features so that it can provide satisfaction for its users.

The sophistication of mobile phones today cannot be separated from the role of the internet, which accesses it increasingly easy and cheaper. With mobile phones evolving into smartphones and internet connection, it becomes a tool of satisfying needs that can make the user dependent, especially among young people and students.

Mobile phones for students are not only for communication, but also they use it to access information, create social networks, connect their hobbies and interests, even as a tool of livelihood. This has changed the original function of a 
mobile phone that was originally only for calling and sending texts into a sophisticated tool that can provide satisfaction among students.

This phenomenon has become a common occurrence in various regions, as well as what happened to students at SMAN 1 Pangalengan Bandung. Their daily lives cannot be separated from their mobile phones. The school policy that does not prohibit carrying mobile phones has opened opportunities for students to use them in the school environment. Based on preliminary observation, the use of mobile phones among students is not only for calling and texting but also as a medium of entertainment now. This can be seen from the tendency of students to prefer to use mobile phones to play games, access YouTube, Facebook, WhatsApp, Instagram, to browse, take selfies, make videos, and play games than to call or send texts. The hypothesis above provides a presumption to the researcher that there have been indications of changes in communication patterns and student interactions between mobile phone users among students of SMAN 1 Pangalengan.

Many studies are related to this research, but most of the previous studies discuss the impact and influence on social life, education, learning, economy, culture, socialization, and interaction. Such as research (Hasanah \& Kumalasari, 2015) which suggests that cellphones cause a decrease in the intensity of students' indirect interaction and cause students to be more individualistic. Then the research (Marsal \& Hidayati, 2017) raises the theme of the influence of smartphones on social interactions which get findings of smartphone use which has an impact on the tendency of students to be more individual and less sensitive to the environment. Furthermore, research that has been carried out by (Supriatno \& Romadhon, 2017) has found that understanding smartphones can be one of the obstacles to face-to-face interaction. This is because of the interaction patterns that can be facilitated by mobile phones.

This is not much different from the research results (Istiyanto, 2016) which confirms that there have been changes in attitudes, mindsets, and ways of communicating with children using mobile phones. This is due to the information they access via mobile phones. It is different from the results of research (Chaudhury \& Tripathy, 2018) regarding smartphone addiction which found the concept that smartphones can be the cause of poor social relationships, especially in interacting with friends, family and have the potential to interfere with health. Meanwhile, what distinguishes this research from others is that it is the object of the study, where we try to provide the view that mobile phones have experienced a shift in their use, especially among students of SMAN 1 Pangalengan.

The purpose of this study was to identify the shift in mobile phone use among students of SMAN 1 Pangalengan. From the results of this study, the researcher hope that it can be used as a preferences for further researchers in studying, analyzing, exploring problems that may occur in the future due to the shift in the use of cell phones among students. 


\section{RESEARCH METHODS}

This study used a survey method with a descriptive analysis conducted at SMAN 1 Pangalengan. The data obtained were the results of a survey conducted on a sample of 100 students from a population of 1,197 spread over various levels ranging from grade 10, grade 11, and grade 12 . On the other hand, the data was also strengthened by the results of interviews with several students. The results of the questionnaire are in percentages to see the extent of shifts or changes in cell phone use and are described.

The indicators show how the intensity of students use the mobile phone for calling purposes, sending texts/short messages (SMS), opening the Facebook application, opening the Instagram application, opening the WhatsApp application, and accessing social media, as well as for browsing, and to play games both online and offline.

The data analysis process includes the stage of collecting, presenting, and concluding (Sugiono, 2013) and presented descriptively.

\section{RESULTS AND DISCUSSION}

The initial function of a mobile phone was to make it easier to make calls and send short messages (SMS). However, in its development, there has been a shift in use where it is not just calling and texting, more than that the mobile phone can be used as a medium of entertainment with the various applications it has. This study tries to identify the shift in mobile phone use among students. The data result is presented in percentage form and it will be described further.
To see the change or shift in the use of mobile phones among students, first of all, the researcher must know how much the students tend to use mobile phones to call or send texts. The following picture is data on students who use mobile phones to call and send texts (SMS) seen from the intensity of their use.

\section{Use Cell Phones to Make Calls}

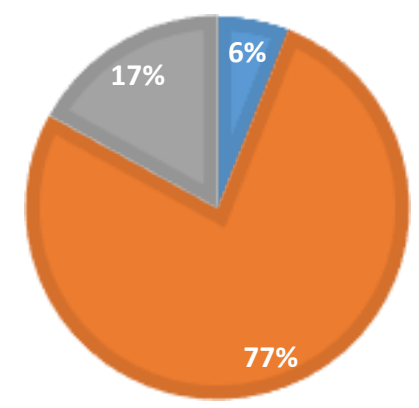

Picture 1. The Use of Cell Phones to Make Calls among Students

Note:

Never

Sometimes

Often

The picture above shows the intensity of students using mobile phones for calling purposes. From the data above, it can be seen that only 17 people often use mobile phones to make calls, 77 people sometimes use mobile phones to make calls, and 6 people don't use mobile phones at all to make calls. This shows that the use of cell phones for calling purposes is very low among students. The picture below shows the use of send texts (SMS) among students. 


\section{Use Cell Phones to Send SMS}

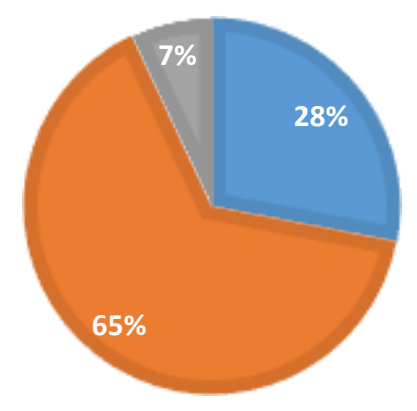

Picture 2. The Use of Cell Phones to Send Short Messages (SMS)

Note:
Never
Sometimes
Often

The picture above shows that to send texts only 7 people often use their mobile phones to send texts, 65 people sometimes, and 28 people never even use their mobile phones to send short messages. The data above is data that is used as a basis for seeing the extent of the shift in mobile phone use among students. Furthermore, the data above will be compared with the use of mobile phones to access social media such as Facebook, Instagram, and WhatsApp. First, the picture below shows at the use of mobile phones to access Facebook.

\section{Use Mobile Phone to Access Facebook}

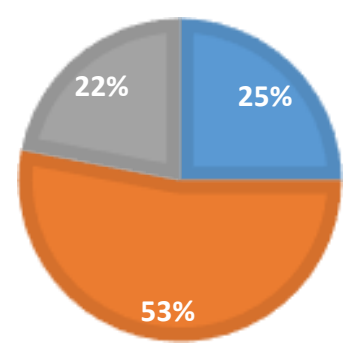

Picture 3. The Use of Mobile Phones to Access Facebook

Note:
Never
Sometimes
Often

The use of mobile phones to access Facebook among students is almost equal between those who often do not and those who have not. The data shows 25 people never use mobile phones to access Facebook and 22 people frequently. Meanwhile, 53 people sometimes use mobile phones to access Facebook. Second, the data below shows the use of mobile phones to access Instagram.

\section{Use Mobile Phone to Access Instagram}

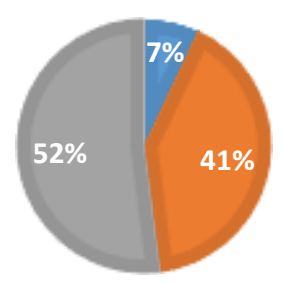

Picture 4. The Use of Mobile Phones to Access Instagram Note:

Never

Sometimes

Often 
For this data, it turns out that the use of mobile phones to access Instagram is quite large. 52 people frequently, 41 students sometimes, and only 7 students who never use their mobile phones to access Instagram. Next, the picture below is the data of mobile phones' usages to access WhatsApp

\section{Use Mobile Phone to Access WhatsApp}

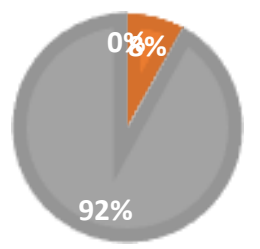

Picture 5. The Use of Mobile Phones to Access WhatsApp

Note:

Never

Sometimes

Often

The data above confirms that the use of mobile phones to access WhatsApp is very large. It can be seen that only 8 people sometimes and the remaining 92 people often use mobile phones to access WhatsApp, there is not even one who does not use a mobile phone to access

\section{Use Mobile Phones to Access} Social Media

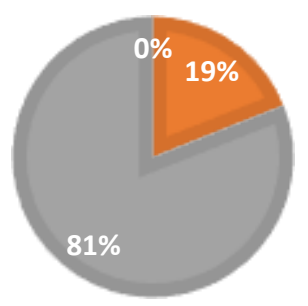

Picture 6. The Use of Mobile Phones to Access Social Media
Note:

Never

Sometimes

Often

From the result it shows that the use of mobile phones to access social media is very high. The data above shows that 81 people use mobile phones to access social media and only 19 people use it occasionally, even no one has never used a mobile phone to access social media.

Apart from accessing social media, students also use mobile phones to search for learning materials, access YouTube, and play games. More details can be seen in the following chart.

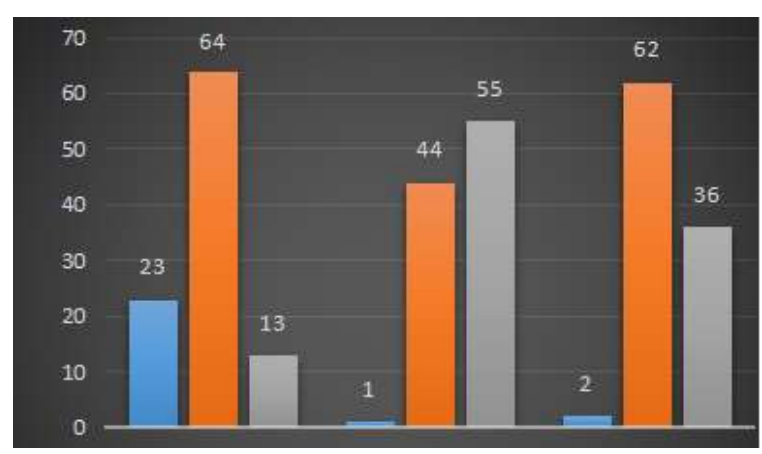

Chart 1. The Use of Mobile Phones to Access Learning Materials, YouTube, and Play Games Note:

Never

Sometimes

Often

The use of mobile phones among students in this area is not very significant. It can be seen from the data above that only $13 \%$ of students often use mobile phones to play games, $35 \%$ of students who frequently use mobile phones to access YouTube, just to access subject 
matter slightly increased with 55\% of students who often do it.

\section{FINDING AND DISCUSSION}

From picture one and picture two, it can be seen that the use of mobile phones for calling and sending texts is very low. From the result above for mobile phone use, only 17 students often use mobile phones to make calls, and only 7 students use mobile phones to send texts. This shows that there has been a change in mobile phone function among students from its basic function as a tool of communication by the results of research (Supriatno \& Romadhon, 2017) which stated that there has been a paradigm shift in the use of mobile phones caused by the development of the mobile phone itself.

This data is strengthened by interview data about why students rarely use their mobile phones to calling and texting. The reason students rarely even use mobile phones to call and send text is because of the high cost of call and text services. Students call or send texts if there is a bonus from purchasing credit or purchasing internet quota packages.

Students are people who mostly use mobile phones for entertainment, connecting their hobbies, looking for references, and some who use mobile phones for entrepreneurial purposes (Lima Ribeiro, Reis Nunes, \& Rocha Amorim, 2017). As for the costs is used for all of this, most of them get money from their parents so that there are limitations in the material and purchasing power made by students. This is consistent with the results of the survey at the time of the study which showed that only $5 \%$ of students bought credit and internet quota from their own business by selling online or offline, working after school or others, while $95 \%$ relied on their parents.

Meanwhile, the use of mobile phones is more widely used to access other applications. From picture three, it can be seen that 22 students often access Facebook through mobile phones. Then from picture one and picture two, it can be seen that only 17 students often call by mobile phones and only 2 students who frequently send texts. From these data, it can be seen that students are more interested in using mobile phones to access the Facebook application than in calling and sending texts. This is reinforced by the results of interviews with students about why they use Facebook so much? The answer is "because Facebook is not only a medium of communication, but we can see other people's activities through the status or photos they upload, we can also save photos or videos, can confide in, can comment on status or photos of friends and even other people. There are lots of fun on Facebook. And I've made a Facebook account several times. Now I only have 2 Facebook accounts. One is my real name, and the other is a pseudonym".

This shows that there is a tendency for students to be more interested in using mobile phones to access the Facebook application than to call or send texts because Facebook is more fun than just calling and texting.

By using Facebook wisely, this application is able to provide great benefits. In the world of education, Facebook can facilitate online interaction between its users. As a sizeable social media platform, Facebook can have a 
positive impact on the world of education and its implementation is easy because most students have social media accounts (Al-Dheleai \& Tasir, 2017).

It cannot be denied that the Facebook application is still very popular among students. Not just as a medium for socializing, moreover, there are many other facilities provided by Facebook for its users. The findings of the study (Jordaan \& VanHeerden, 2017) state that at this time Facebook can be a part of young people's lives, life, and daily routines are not far from Facebook and will be very disappointed if Facebook does not exist anymore one day.

There are so many benefits of Facebook for those who are able to take advantage of it, for example, we can find information about our friends or distant relatives, who may have been separated for a long time, or share missing information, or share other information, whether important or not. In addition, Facebook can also facilitate large social media groups with unique names depending on the purpose of creating the group. For example the Lombok info group, which contains information about Lombok, or Bandung regency info that informs you about everything the latest about Bandung, or even groups about the same hobbies, for example, groups that love cats, dogs, birds, and others, or professional groups, groups field of science, buying and selling group, and others. This shows that Facebook has many advantages compared to just calling and texting so it has more users. Although so far there have been many studies on the negative impact of Facebook, there are also many positive findings in the research that show that Facebook has benefits.
Such as research from (Naqshbandi, Ainin, Jaafar, \& Mohd, 2017) which suggests that Facebook can be used as a way to exchange information, learning, self-development, so that it could improve learning outcomes.

Next, picture four shows the use of mobile phones to access Instagram. The data above shows that as many as $52 \%$ of students often access this application through mobile phones. This is quite a difference compared to the use of mobile phones as its main function as a tool of calling and sending texts.

Not much different from Facebook, Instagram is also a social media that can be used as a medium for self-actualization. On there, people can share their daily life, activities, even achievements through videos and photos and even as a tool of promotion and business. Instagram is used to see the activities of someone, it can be friends, family, even celebrities. More than $70 \%$ of young people in the world use Instagram and their motivation use Instagram is to see someone's posts (Huang \& Su, 2018). This is not much different from the findings of (Sheldon \& Bryant, 2016) which suggest that the motive for using Instagram was as a medium of documentation, supervision of others, developing creativity and as a medium for narcissism. This was a way of self-actualization.

The various facilities provided by the Instagram application make this application much in demand by young people. Social media with pictures and videos can reduce loneliness for its users. In addition, a photo is used as an effective communication medium because it could convey the expressions, feelings, or 
situations they are experiencing (Pittman \& Reich, 2016).

The next discussion is about students who use mobile phones to open the WhatsApp application. Picture five above shows that the level of use of this application among students is very high. It can be seen that $92 \%$ of students use it often and only 8 people sometimes. The results of the interview stated that the reason students opened WhatsApp more often than calling or texting was that WhatsApp was cheaper and more fun. Like the following interview excerpt, "pami nelepon sareng SMS mah awis, tapi WhatsApp mah mirah, terus Whats App mah tiasa nelepon oge, tiasa ngechat, videa call oge, terus tiasa oge ngirim rekaman, ngirim photo, video, ngadamel status. Teras urang tiasa ngadamel grupgrup. Jadi ngobrolna tiasa seueuran henteu jiga SMS. Tiasa kerja sama, tiasa diskusi, pokona seueur ue pak resep pokonaman", which means" if we call and send texts, it is expensive but WhatApp is cheaper, and WhatsApp can make calls like a mobile phone, can send messages, send photos, send videos, and create status. We also create groups, so we can chat with many friends at once, unlike texting just the two of us. Can work together, can discuss, the point is many points, Sir, and it is fun ". These findings confirm the tendency of students who have rarely used mobile phones to call and send texts and switch to use WhatsApp.

WhatsApp has almost the same main function with mobile phone, to make calls and send messages. The difference is if conventional call and texts use regular credit, but WhatsApp application uses internet quota. Another similarity is to use a mobile phone number to activate and automatically our number will be registered as a WhatsApp user if our mobile phone has the application. Its advantages lie in its wide coverage in the field of information sharing such as access to photos, videos, voice recording media, or others (Akinlosotu, 2016). This condition makes WhatApp users increase day by day. Many studies have revealed the high use of WhatsApp among students. Like the results of research (Rajini, Kannan, Alli, \& Tamilaevi, 2018) which was carried out at the Private Medical College, Pondicherry found that most students have used WhatsApp and $87 \%$ of them spend their time chatting through WhatsApp. The same thing was also found by (Singh et al., 2019). They mentioned that 247 male students and 157 female students use WhatsApp in their daily lives. The frequency of using WhatsApp that they do is among 84 people less than 5 times a day, 169 between 6-20 times per day, and the remaining 146 open WhatsApp more than 20 times a day. From the data above, the researcher conclude that the tendency to use WhatsApp does not only occur in SMA Negeri 1 Pangalengan, but also on most Abudhabi students which is in accordance with the findings of (Kootbodien, Prasad, \& Ali, 2018) and in this reserach, most of the respondents said say that WhatsApp is a social media application that is quite effective even though sometimes it often causes miscommunication.

The main function of the mobile phone as a tool of communication making it easier to call and send texts has turned into a medium that is more than just that. In Picture six, it can be seen that $81 \%$ of students often use mobile phones to access social media and $19 \%$ do not necessarily 
use mobile phones to call and send texts. However, this shift does not eliminate the main function of mobile phones, as a tool of communication, only communication patterns have changed (Kaya \& Bicen, 2016).

\section{CONCLUSION}

From this research, the researcher concludes that the use of mobile phones which originally served to call and send texts has experienced a shift. The results of the analysis shows that $92 \%$ of students use WhatsApp to communicate and $82 \%$ of students use mobile phones to access social media. Meanwhile, $17 \%$ of students use mobile phones to make calls so that it can be concluded that although it does not eliminate the main function of mobile phones as a tool of communication, communication patterns have developed. Previously, mobile phones were only used for calling and texting, but now the use of it is even wider with the proliferation of social media which is more attractive to use among students of SMAN 1 Pangalengan.

\section{REFERENCES}

Akinlosotu, T. (2016). Predictors of WhatsAPP 'Consumption' among undergraduate students of Economics in Ambrose Alli University, Ekpoma. African Research Review, 10(3), 290. https://doi.org/10.4314/afrrev.v10i $\underline{3.19}$

Al-Dheleai, Y. M., \& Tasir, Z. (2017). Using facebook for the purpose of students' interaction and its correlation with students' academic performance. Turkish Online Journal of Educational Technology, 16(4), 170-178.

Chaudhury, P., \& Tripathy, H. K. (2018). A study on impact of smartphone addiction on academic performance. International Journal of Engineering and Technology(UAE), 7(2), 50-53. https://doi.org/10.14419/ijet.v7i2.6 .10066

Hasanah, N., \& Kumalasari, D. (2015). Penggunaan Handphone dan Hubungan Teman Pada Prilaku Sosial Siswa SMP Muhammadiyah Luwuk Sulawesi. Harmoni Sosial, 151(1), 10-17. https://doi.org/10.1145/3132847.3 132886

Huang, Y. T., \& Su, S. F. (2018). Motives for instagram use and topics of interest among young adults. Future Internet, 10(8). https://doi.org/10.3390/fi10080077 Indraswati, D., Marhayani, D. A., Sutisna, D., Widodo, A., \& Mauilida, M. A. (2020). critical thinking dan problem solving dalam pembelajaran ips untuk menjawab tantangan abad 21. Sosial Horizon, Jurnal Pendidikan Sosial, 7(1), 1228. Diambil dari https://journal.ikippgriptk.ac.id/ind ex.php/sosial/article/view/1540

Istiyanto, S. B. (2016). TELEPON GENGGAM DAN PERUBAHAN SOSIAL Studi Kasus Dampak Negatif Media Komunikasi dan Informasi Bagi Anak-Anak di Kelurahan Bobosan Purwokerto Kabupaten Banyumas. Jurnal Komunikasi Ikatan Sarjana 
Komunikasi Indonesia, 1(1), 58. https://doi.org/10.25008/jkiski.v1i $\underline{1.36}$

Jordaan, Y., \& VanHeerden, G. (2017). Online privacy-related predictors of Facebook usage intensity. Japanese Journal of Radiological Technology, 70(5), 90-96. https://doi.org/10.6009/jjrt.KJ0000 3534360https://doi.org/10.1016/j.c hb.2016.12.048

Kaya, T., \& Bicen, H. (2016). The effects of social media on students' behaviors; Facebook as a case study. Computers in Human Behavior.

https://doi.org/10.1016/j.chb.2016. $\underline{02.036}$

Kootbodien, A., Prasad, N. V., \& Ali, M. S. B. S. (2018). Trends and impact of WhatsApp as a mode of communication among Abu Dhabi students. Media Watch, 9(2), 257266.https://doi.org/10.15655/mw/2 018/v9i2/49380

Lima, Ribeiro, J. da C., Reis Nunes, R. dos, \& Rocha Amorim, R. J. (2017). The Use of Cell Phones in School: Hybridization of Knowledge and Teaching Practices. Creative Education, 08(12), 1968-1990. https://doi.org/10.4236/ce.2017.81 $\underline{2134}$

Marsal, A., \& Hidayati, F. (2017). Pengaruh Smartphone Terhadap Pola Interaksi Sosial Pada Anak Balita Di Lingkungan Keluarga Pegawai Uin Sultan Syarif Kasim Riau. Jurnal Ilmiah Rekayasa dan Manajemen Sistem Informasi, 3(1), 78-84.
Naqshbandi, M. M., Ainin, S., Jaafar, N. I., \& Mohd, S. N. L. (2017). To Facebook or to Face Book? An investigation of how academic performance of different personalities is affected through the intervention of Facebook usage. Computers in Human Behavior, 75, 167-176. https://doi.org/10.1016/j.chb.2017. $\underline{05.012}$

Pittman, M., \& Reich, B. (2016). Social media and loneliness: Why an Instagram picture may be worth more than a thousand Twitter words. Computers in Human Behavior, 62, 155-167. https://doi.org/10.1016/j.chb.2016. $\underline{03.084}$

Rajini, S., Kannan, K., Alli, P., \& Tamilaevi, V. (2018). Study on Prevalence of Whatsapp Addiction among Medical Students in A Private Medical College, Pondicherry. Indian Journal of Public Health Research and Development, 9(7), 113-116. https://doi.org/10.5958/09765506.2018.00637

S, Mulyanta, E. (2005). Kupas Tuntas Telepon Seluler Anda. Yogyakarta: ANDI.

Sheldon, P., \& Bryant, K. (2016). Instagram: Motives for its use and relationship to narcissism and contextual age. Computers in Human Behavior, 58, 89-97. https://doi.org/10.1016/j.chb.2015. 12.059

Singh, N., Singh, N. P., Kharya, P., Shukla, S., Singh, V., \& Raj Singh, D. (2019). Whatsapp addiction: assessing pattern of 
Whatsapp usage and its impact on medical students at U.P.U.M.S., Saifai, Etawah, India. International Journal Of Community Medicine And Public Health, 6(6), 2505. https://doi.org/10.18203/23946040.ijcmph20192312

Sugiono. (2013). Metode Penelitian Pendidikan (Pendekatan Kuantitatif, Kualitatif, dan R\&D). Bandung: Alfabeta.

Supriatno, D., \& Romadhon, I. (2017). Pengaruh Media Komunikasi
Smartphone Terhadap Interaksi Sosial Pelajar (Studi Deskriptif Kuantitatif pada Pelajar SMK Astra Nawa Ambulu). Paradigma Madani, 4(2), 65-74.

Widodo, A., Indraswati, D., \& Sobri, M. (2019). Analisis Nilai-Nilai Kecakapan Abad 21 Dalam Buku. Jurnal Tarbiyah: Jurnal Ilmiah Kependidikan, 8(2), 125-133. https://doi.org/10.18592/tarbiyah.v $\underline{8 \mathrm{i} 2.3231}$ 